Niepodległość. Idee, fakty, perspektywy. W 100. rocznicę odzyskania niepodległości przez Polskę, red. P. Krokosz, S. Romański-Cebula, Kraków 20I9, s. 33-49

DOI: http://dx.doi.org/Io.15633/9788374388085.03

\title{
Szkoła jako podstawowe miejsce kształtowania postaw społeczno-politycznych - gimnazjum na Smolnej 30 w Warszawie w I połowie XX wieku
}

\section{Abstrakt}

Artykuł przedstawia wpływ szkoły na proces kształtowania postaw społeczno-politycznych młodego pokolenia na przykładzie gimnazjum na Smolnej 30 w Warszawie w I połowie XX wieku. Od samego początku na terenie szkoły działały uczniowskie grupy konspiracyjne o orientacji narodowej i socjalistycznej. Na przełomie lat 20. i 30. XX wieku w gimnazjum na Smolnej zdobywało wyksztalcenie wielu późniejszych działaczy Związku Akademickiego Młodzież Wszechpolska oraz ugrupowań narodowo-radykalnych, w tym przyszli liderzy Obozu Narodowo-Radykalnego: Jan Mosdorf, czy Ruchu Narodowo-Radykalnego „Falanga” - Jerzy Hagmajer, Wojciech Kwasieborski oraz Bolesław Piasecki.

Stowa kluczowe:

Obóz Narodowo-Radykalny, Ruch Narodowo-Radykalny „Falanga”, Jan Mosdorf, Bolesław Piasecki, młodzież, niepodległość Polski

\section{Abstract}

School as a basic place of formation of socio-political attitudes - grammar school at Smolna 30 in Warsaw in the first half of the XXth century.

The influence of school on the process of formation of socio-political attitudes of the young generation, on the example grammar-school at Smolna 30 in Warsaw in the first half of the XXth century is presented in the article. From the very beginning students conspiratorial groups having national and socia- 
list orientation acted at school. On the turn of the 20 s and 30 s of the XXth century in grammar-school on Smolna many later of activists of Academic Association of All-Polish Young People and national-radical formations were educated. Among them there were leaders of the National Radical Camp: Jan Mosdorf, as well as Jerzy Hagmajer from the National Radical Camp "Falanga", Wojciech Kwasieborski and Bolesław Piasecki.

Keywords

National Radical Camp, National Radical Camp the "Falanga", Jan Mosdorf, Bolesław Piasecki, young people, the independence of Poland

GIMNAZJUM NA SMOLNEJ 30 - SYMBOL REWOLUCJI Z I9O5 ROKU

Powstawanie gimnazjum na Smolnej $30 \mathrm{w}$ Warszawie przypadło na gorący okres polityczny, kiedy podczas trwającej wojny rosyjsko-japońskiej pojawiła się nadzieja na zmianę sytuacji w zaborze rosyjskim. W styczniu I905 roku po tzw. „krwawej niedzieli” zaczęły wybuchać masowe strajki, które niedługo później rozprzestrzeniły

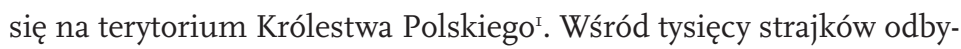
wał się także powszechny strajk szkolny na terytorium warszawskiej politechniki i uniwersytetu, rozszerzając się następnie na młodzież warszawskich szkół średnich i zawodowych oraz inne miasta. Domagał się on przede wszystkim wprowadzenia do szkół języka polskiego oraz powszechnego i bezpłatnego dostępu do edukacji. W wyniku strajków władze carskie poszły na częściowe ustępstwa w zaborze rosyjskim: wprowadzono wolność wyznania, dopuszczono używanie języka polskiego w urzędach gminnych, zgodnie z decyzją cara z 2 września ı905 roku w Królestwie Polskim mogły powstawać prywatne szkoły z wykładowym językiem polskim. Z nowego prawa błyskawicznie

I Por. J. Miąso, Walka o narodowa szkołe w Królestwie Polskim w latach 19051907 (w stulecie strajku szkolnego), ,Rozprawa z Dziejów Oświaty” 44 (2005), s. 88 . 
skorzystał emerytowany oficer wojsk rosyjskich gen. Paweł Chrzanowski, który utworzone na ul. Wielkiej (dziś Poznańskiej) w I903 roku prywatne gimnazjum z prawami rządowymi przekształcił w polską szkołę (z zastrzeżeniem, że język rosyjski, geografia i historia będą prowadzone po rosyjsku przez Rosjan), rezygnując z praw rządowych (co oznaczało m.in. nieuznawanie przez władze rosyjskie zdanej tu matury) w zamian za prawo nauczania w języku polskim. Szukając dla szkoły stałego miejsca, gen. Chrzanowski nabył od hr. Ksawerego Branickiego jeden z domów wznoszonych przy ul. Smolnej 30. Gimnazjum im. gen. Chrzanowskiego otwarte 23 października I905 roku było symbolem zachodzących przemian, pierwszą szkołą polską w Królestwie Polskim i największą szkołą średnią na obszarze wszystkich trzech zaborów, w której w 27 klasach uczyło się około I480 uczniów²

\section{KSZTAŁTOWANIE POSTAW NIEPODLEGŁOŚCIOWYCH I POLITYCZNYCH}

Pomimo wielu problemów w początkowych latach istnienia szkoły wśród uczniów panowała patriotyczna i podniosła atmosfera, jak wspomniał po latach jeden z absolwentów: „Młodzież była świadoma swego pierwszego tryumfu. Zwycięstwo w walce o szkolę polską dało jej wiarę w siebie. Zapragnęła dalszych zwycięstw, marzyła o wskrzeszeniu niepodległej Polski”3. Po latach strajków szkolnych coraz bardziej dominowały niepodległościowe i powstańcze nastroje, co doskonale obrazują wspomnienia Melchiora Wańkowicza, który opisując okres nauki w Gimnazjum im. gen. Chrzanowskiego w latach I904-I9II, pisał m.in.:

2 Por. 100 lat na Smolnej, czyli dzieje Gimnazjum i Liceum Jana Zamoyskiego w Warszawie, oprac. aut. U. Golnik-Szczególska, M. Szczygielska, B. Kozyra, współpr. A. Grocholska, E. Kędziorek, Warszawa 2005, s. I3-I4; Por. T. Kwiek, Nasza Szkoła 1905-1939, w: Smolna 30: Gimnazjum im. Jana Zamoyskiego, red. J. Durko, T. Kwiek, Warszawa I989, s. I3-15.

3 A. Śledziński, O strajku szkolnym i o pierwszej szkole polskiej, w: Smolna 30..., dz. cyt., s. 98 . 
Dwa lata była prowadzona szkoła przez nauczycieli Rosjan. Odsiadywaliśmy raz po raz karcery za mówienie na pauzach po polsku. Po strajku szkolnym powołana do życia polska szkoła nie od razu uchwyciła równowagę. Wlała się do tej szkoły młodzież odurzona sukcesem, zbratana z rewolucyjną ulicą [...]. W krótkim okresie między rewolucją w I905 roku a wybuchem wojny w I9I4 szkoły Polskie nie miały praw i zmuszone były pobierać większe wpisowe niż szkoły rządowe. Na skutek tego potrzebny był nieustanny wysiłek, by utrzymywać w sile bojkot szkół rosyjskich. Ponieważ nie mieliśmy w Warszawie uniwersytetu, ciężar prowadze nia akcji spadł na młodzież szkół średnich, która organizowała konspirację rozszerzoną na trzy zabory, drukowała tajne pismo, urządzała zjazdy dzielnicowe i trójzaborowe. Bardzo wiele osób odsiadywało więzienia

W pracy Bez Przyłbicy, wspólnej księdze maturzystów z I9II roku, mottem dla absolwentów stał się cytat z wiersza Marii Konopnickiej Nie mogę mówić: „Nie mogę mówić do was, jakbym chciała, ani do głębi serca wam otworzyć... Ale wy wiecie, jak drży i jak pała Słowo to, które pragnę tu położyć" - tym słowem według maturzystów miała być niepodległość. „Byliśmy pokoleniem duchowo dojrzałym do tego hasła" - wspominał Wańkowicz's.

Wraz ze wkroczeniem Niemców do Warszawy i reaktywowaniem wyższych uczelni powolne zmiany w edukacji zaczęły być widoczne również w szkołach średnich, w których zmianie uległ program nauczania, co ilustruje sytuacja w Gimnazjum gen. Chrzanowskiego na Smolnej 30 w Warszawie. Od I9I5 roku zaczęto uczyć języka polskiego w pełnym wymiarze, wprowadzono zakazane dotychczas historię i geografię Polski. Gimnazjum przeżywało nadal liczne trudności finansowe, które pojawiły się jeszcze przed zamachem w Sarajewie, gdy 3I marca I9I4 roku zmarł gen. Chrzanowski, a wdowa po nim, Cecylia, po wybuchu I wojny światowej utraciła możliwość finansowania szkoły. Aby ratować spuściznę generała, zawiązano komitet, na czele którego stanął adwokat Władysław Piechowski, a potrzebne pieniądze wyasygnował znany polityk, działacz endecki Maurycy hr. Zamoyski. Szkoła przyjęła wówczas nową nazwę - Gimnazjum

4 M. Wańkowicz, Przez trzy epoki, w: Smolna 30..., dz. cyt., s. I I5.

5 M. Wańkowicz, Przez trzy epoki, w: Smolna 30..., dz. cyt., s. I I4. 
Towarzystwa Szkoły Maurycego hr. Zamoyskiego ${ }^{6}$. Warunki panujące w szkolnictwie polskim pod okupacją niemiecką, choć ulegały nieznacznej poprawie, powodowały dominację atmosfery niepewności jutra, co doskonale oddaje sprawozdanie dyrektora z roku szkolnego I9I5/16, w którym można przeczytać, że:

Od roku polskie szkolnictwo średnie znajduje się w sytuacyi zmienionej. Jeżeli całość jego organizmu pod względem sprawności i jednolitości funkcyonowania, jeżeli interwencya sił społecznych w zarządzie i urządzaniu szkoły przedstawia się problematycznie, to w każdym razie wewnątrz murów szkolnych wionął większy duch swobody. Warunki ogólne życia społecznego oraz sytuacya na szerokiej widowni świata, od której te warunki zależeć muszą, nie przedstawiają się jasno ani też pozwalają na jakikolwiek ryczałtowy sąd o przyszłości życia naszej szkoły. Stąd niepewność wobec jutra, stąd też ostrożność konieczna przy gruntowniejszem modyfikowaniu zarówno ustroju szkolnego jak programów nauczania, ostrożność ze wszech miar wskazana, gdyż niema nic szkodliwszego w wychowaniu, jak raptowne, zależne od przygodnych powiewów opinii lub nastroju zmiany gruntowne w planie szkolnym [...] Gimnazyum Towarzystwa Szkoły M. hr. Zamoyskiego istnieje od roku, t. j. od czasu, kiedy, jak wspomniano wyżej, rozpoczęła się era większej swobody. Dawny jego program zatwierdzony po długich pertraktacyach przez władze rosyjskie musiał ulec zmianie wobec nowych warunków. Przy tej zmianie kierownictwo szkoły usiłowało główny nacisk położyć na spolonizowanie uczelni naszej, na postawienie nauki historyi i geografii Polski oraz języka ojczystego na poziomie, godnym szkoły polskiej.

Odzyskiwanie przez Polskę niepodległości w I9I8 roku zbiegło się w czasie z kolejnymi zmianami w gimnazjum. Na zebraniu Towarzystwa Maurycego hr. Zamoyskiego Io listopada I9I8 roku uchwalono zmianę nazwy szkoły na Gimnazjum Towarzystwa im. Jana Zamoyskiego, a w Akcie Fundacyjnym Akademii Zamoyskiej znalazły się znamienne słowa: „Takie będą Rzeczypospolite, jakie ich młodzieży chowanie", które przyświecać miały nauczycielom i wychowawcom „Zamoyskiego”, co, jak się niedługo później okazało, nie było frazesem,

6 Por. T. Kwiek, Nasza Szkoła 1905-1939, w: Smolna 30..., dz. cyt., s. 20-2I.

7 Gimnazjum Towarzystwa Szkoty Maurycego Hr. Zamoyskiego. Sprawozdanie z Działalności Towarzystwa Szkoły Maurycego Hr. Zamoyskiego w Roku Szkolnym 1915/16, Warszawa I9I6, s. 4-5. 
gdyż nauczyciele oraz uczniowie gimnazjum na Smolnej 30 wzięli aktywny udział w kształtowaniu granic odradzającego się państwa Polskiego, m.in. w wojnie polsko-bolszewickiej ${ }^{8}$. Po zakończeniu roku szkolnego w czerwcu I920 roku, jak wspominał Tadeusz Kwiek, „radośnie żegnający się ze szkołą na dwa miesiące zamojszczacy nie przypuszczali, jakie czekają ich wakacje. Wojna polsko-radziecka tego gorącego lata weszła w kulminacyjną fazę, rozpoczął się zaciąg ochotników. Ruszyli więc zamojszczacy ławą do szeregów. Klasy ósme poszły w pole w całości, z młodszych, aż do piątej - bardzo wielu”. „Słowa pieśni «wojenko, wojenko cóżeś ty za pani» z dalekich widnokręgów świata miały w ich kroczyć życie. «Woienka» stała na granicach juz od szeregu miesięcy lecz nikt w czerwcu i920 r. nie przepuszczał, że dłonią po Warszawę sięgnie. Dopiero przecież I2.VI. wycofywać się poczęło nasze wojsko z Kijowa, dopiero na odległym północnym froncie gromadzić się poczęły uderzeniowe armie rosyiskie. Tragiczne dni zaskoczyły więc naszych uczniów na wakacjach”ㅇ․

Mundury wojskowe przywdziało również siedmiu profesorów gimnazjum: nauczyciel rysunku Kazimierz Borzym, polonista Marian Kaczyński, historyk Kazimierz Krzymuski, polonista Juliusz Nowak-Dłużewski, przyrodnik Leon Rówieński, gimnastyk Bronisław Sosiński, filolog klasyczny Wiktor Wąsik. „Taki to był więc rok - pisał Kwiek - profesor i uczeń o dziwo niepojęte - razem szli «na wagary»" "I. Z początkiem nowego roku szkolnego I920/I92I „klasy świeciły pustkami, brakowało też nauczycieli, trzeba było improwizować zastępstwa. Dopiero gdy działania wojenne zaczęły dogasać, stopniowo powracali profesorowie, i uczniowie, w miarę jak ich z wojska zwalniano. Przed szkołą wyrosło jednak zagadnienie ponownego wdrożenia niedawnych żołnierzy do uczniowskiej dyscypliny. Były niewątpliwe trudności, lecz udało się je opanować. Najlepszym zwierciadłem tych nastrojów - były

8100 lat na Smolnej..., dz. cyt., s. I7-18,

9 T. Kwiek, Nasza Szkoła 1905-1939, w: Smolna 30..., dz. cyt., s. 24-25.

IO T. Kwiek, Historia gimn. Tow. im. Jana Zamoyskiego. Lista nauczycieli gimnazjum i szkoły powszechnej Tow, „Życie Szkoły: Organ Samorządu Szkolnego Uczniów Gimnazjum im. Jana Zamoyskiego” (dalej „Życie Szkoły”) 65 (I938), s. 5.

I I T. Kwiek, Historia gimn. Tow. im. Jana Zamoyskiego..., dz. cyt., s. 6. 
słowa Józefa Janoty Bzowskiego, prezesa Koła Szkolnego, na powitalnej uroczystości ucznia-żołnierza w dniu 7 grudnia I920 roku: «Strzeż się dziś, młodzieży, pychy i zarozumiałości [...]. Powiedz: Dla Ciebie, Polsko, i bohaterstwo twoje [...] przekaż księgom historii. Nie kuj z niego dziś, gdy wracasz na ławę szkolną, broni, utrudniającej wychowawcom twoim ich pracę...»"

Gimnazjum na Smolnej 30 od powstania stanowiło szczególne miejsce w Warszawie, w którym nie sposób było uciec od polityki i ówczesnych problemów, a wśród młodych uczniów rodziły się przyjaźnie, sympatie polityczne i powstawały organizacje konspiracyjne i samopomocowe. Według Kwieka:

Społeczność uczniowska pulsowała życiem, działała półjawnie, boć powstała bratnia pomoc oraz konspiracyjne komórki polityczne o orientacji narodowej i socjalistycznej, czego zarówno dyrekcja, jak i nauczyciele „nie zauważali”, wychodziły na terenie szkoły („Dzwon”, „Siew”, „Osa”), potajemnie odbijane metodą litograficzną. Dyskutowano w kółkach samokształcenia, słuchano odczytów, odbywały się zabawy ${ }^{\mathrm{r} 3}$.

Z kolei Wańkowicz wspominał: „socjaliści i nacjonaliści na wszystkich pauzach staczali boje [...], w łazienkach bywało nas więcej niż w klasie" I4. W I9I9 roku nowym dyrektorem szkoły został Henryk Lipski, późniejszy poseł z ramienia Związku Ludowo-Narodowego, jednak według relacji polonisty Juliusza Nowaka-Dłużewskiego nie wpływał na uczniów i nauczycieli, forsując konkretną ideologięis.

$\mathrm{Na}$ terenie gimnazjum istniała również samopomoc uczniowska, która powstała w roku szkolnym I9I5/I6, nie zachowały się jednak z tamtego czasu statut czy szersze informacje dotyczące organizacji. Okres jej rozwoju rozpoczyna się dopiero wraz z odzyskaniem przez Polskę niepodległości. W zachowanym statucie z I9I9 roku Ustawa Samopomocy Koleżeńskiej, uczniowie gimnazjum za główne

I2 T. Kwiek, Historia gimn. Tow. im. Jana Zamoyskiego..., dz. cyt., s. 25.

I 3 Idem, Historia gimn. Tow. im. Jana Zamoyskiego..., dz. cyt., s. I9.

I4 M. Wańkowicz, Przez trzy epoki, w: Smolna 30..., dz. cyt., s. I I 5.

I5 Por. J. Nowak-Dłużewski, Ze wspomnień polonisty Gimnazjum im. Jana Zamoyskiego (1920-1939). (Na pótwieczny jubileusz szkoły), „Życie i Myśl” 9 (I965), s. 99-107. 
cele organizacji uznawali przede wszystkim „popieranie rozwoju umysłowego i fizycznego swych członków, dopomaganie i ułatwianie w nabywaniu pomocy naukowych" ${ }^{16}$. Samopomoc składała się z sześciu sekcji: biblioteki, czytelni, odczytów, ruchu (zajmującego się sportem i imprezami dochodowymi), antykwarni i sklepiku. Przystępować mogli do niej uczniowie po ukończeniu III klasy, system pracy wybrano półroczny (co pół roku wybory i zmiana prezesa), a w okresie wakacyjnym działała specjalna komisja wakacyjna. Finanse oparte były na składkach, które w przeciągu lat obniżano, prócz tego źródła pewną ilość pieniędzy dawały imprezy z tradycyjnym balem na czele. Na początku lat 20. XX wieku Samopomoc Koleżeńska w Gimnazjum Towarzystwa im. Jana Zamoyskiego rozwijała się doskonale, o czym świadczyć może eksterytorialność jej lokalu, do którego nie mieli prawa wstępu profesorowie, „w ówczesnej atmosferze samopomoce uczniowskie miały z jednej strony większe możliwości działania, niż w latach późniejszych, a z drugiej strony działacze samopomocowi na serio przejmowali się myślą stworzenia «Rzeczypospolitej Uczniowskiej»"

Organizacje gimnazjalne, w tym szczególnie samopomoce, były doskonałym miejscem kształtowania się postaw życiowych i politycznych wielu przyszłych działaczy politycznych, o czym po latach wspominał Jerzy Zagórski:

Życie samopomocowe naszego gimnazjum ukształciło niejednego z późniejszych gladiatorów politycznych, a musiało być bujne, bo rozrzut ideowy naszych wychowanków przedstawia się dość efektownie. Od Rembielińskiego i Mosdorfa poprzez Bolesława Piaseckiego, do takich lewicowców, jak Adamczewski, Librowicz-Mucharski i członek KPP Boniecki, więziony przez ówczesne polskie władze - mamy szeroki wachlarz politycznych działaczy ${ }^{18}$.

Gimnazjum na Smolnej 30 w Warszawie na przełomie lat 20. i 30. było miejscem, w którym wykształcenie zdybywało wielu późniejszych

I6 M. Korwin-Piotrowski, Co w pyle dawnych akt o samorządzie znaleźć można, „Życie Szkoły” 65 (1938), s. 31-32.

I7 M. Korwin-Piotrowski, Co w pyle dawnych akt..., dz. cyt., s. 33.

I8 J. Zagórski, Wywołani do tablicy, w: Smolna 30..., s. I65. 
działaczy Związku Akademickiego Młodzież Wszechpolska ${ }^{19}$, oraz ugrupowań narodowo-radykalnych, w tym liderzy Obozu Narodowo-Radykalnego - Jan Mosdorf oraz Ruchu Narodowo-Radykalnego „Falanga” - Jerzy Hagmajer, Wojciech Kwasieborski oraz Bolesław Piasecki, przez co gimnazjum nazywane było z czasem „wylęgarnią oenerowców" ${ }^{20}$.

W gimnazjalnej samopomocy przyszli oenerowcy od początku lat 20. pełnili ważną funkcję. W latach I920-I922 wiceprezesem, a następnieprezesem tej formacji był Mosdorf, „po zatargach wewnętrznych” wycofując ją z centralnej organizacji skupiającej samopomoce uczniowskie, której prezesem był wówczas socjalistyczny działacz Stanisław Dubois ${ }^{21}$. Nie wiadomo jednak, co było dokładnie powodem tej decyzji - czy walka ideologiczna, czy personalny konflikt obu liderów młodzieżowych organizacji, którzy po 20 latach wspólnie będą toczyć gorące spory podczas osadzenia na Pawiaku ${ }^{22}$ oraz tworzyć konspiracyjny ruch oporu w KL Auschwitz ${ }^{23}$. Z racji wieku Mosdorf nie mógł uczestniczyć w wojnie z bolszewikami, co zarzucano mu wiele lat później na łamach prasy związanej z lewicowo-piłsudczykowskimi organizacjami $^{24}$. Według „Falangi. Pisma Narodowo-Radykalnego” nie uchylał się jednak przed służbą wojskową: ,Jako szesnastoletni chłopiec stanął

I9 Wśród nich byli m.in. prezesi Rady Naczelnej Związku Akademickiego Młodzież Wszechpolska: Jan Rembieliński, Jan Jodzewicz, Jan Mosdorf czy znani działacze jak Stanisław Froelich, Władysław Kempfi, Zbigniew Stypułkowski.

20 W. J. Muszyński, Duch młodych. Organizacja Polska i Obóz Narodowo-Radykalny w latach 1934-1944. Od studenckiej rewolty do konspiracji niepodległościowej, Warszawa 20I I, S. 2 I.

2 I Por. M. Korwin-Piotrowski, Co w pyle dawnych akt..., dz. cyt., s. 33-34.

22 Por. S. Kamiński, Miatem piętnaście lat. Pawiak byt etapem. Wspomnienia lat 1939-1944, Warszawa I987, s. 78-79.

23 Zob. J. Garliński, Oświęcim walczący, Londyn I974; W. Gawron, Ochotnik do Oświęcimia, Oświęcim I992; M. Kotas, Jan Mosdorf. Filozof, ideolog, polityk, Krzeszowice 2007 .

24 „Niema i nie będzie porozumienia z prawicą, jeśli ta będzie chciała rozdawać patenty na honor i patenty na polskość. Nie będzie o nich decydować Mosdorf, chory I920 roku i chory w maju I926, ale zdrów zato jak rozegziony byczek na każdem Walnem Zebraniu”, zob. Echa walnego zebrania, „Kuźnica: Dwutygodnik Młodzieży Demokratycznej” 4 (I928), s. 2. 
przed komisją wojskową w Warszawie, zatajając swój wiek. I dopiero przypadkowa interwencja pana Przyjemskiego (dzisiejszego adwokata), który znał Mosdorfa osobiście - spowodowała - usunięcie młodego chłopca z sali komisji, co odbyło się z dodatkiem odpowiedniej rugi za wprowadzenie władz wojskowych w błąd. Jan Mosdorf odbył zresztą wtedy ochotniczą służbę w straży obywatelskiej”25.

Po zdanej maturze w I922 roku wraz z kolegami z klasy maturalnej Stanisławem Froelichem oraz Józefem Szymańskim tworzył pismo młodzieżowe „Słowo”26. Mosdorf w późniejszych latach nie utracił kontaktu z gimnazjum, m.in. w maju I930 roku na zjeździe byłych wychowanków Gimnazjum im. Jana Zamoyskiego ${ }^{27}$ wygłosił referat dyskusyjny Zagadnienie nadprodukcji inteligencji28.

Dekadę po Mosdorfie, na początku lat 30. prezesurę samopomocy sprawował Bolesław Piasecki, przyszły lider Ruchu Narodowo-Radykalnego „Falanga”, który zaangażował się m.in. w funkcjonowanie uczniowskiego miesięcznika „Życie Szkoły” powstałego w I927 roku²9, w kolejnych latach publikując na jego łamach kilkanaście artykułów,

25 Pejsate wojowniki, zawodowi pacyfiści, dezerterzy i tchórze $w$ roli nauczycieli... męstwa, „Falanga. Pismo Narodowo-Radykalne” 6 (I937), s. 4.

26 K. A. Tyszka, Związki młodzieży narodowej. Rys historyczny procesu powstawania Młodzieży Wszechpolskiej w Warszawie 1915-1922, „Glaukopis” 4 (2006), s. 42,67 .

27 „Stowarzyszenie Wychowanków Szkoły sięga I924 roku, zalegalizowano wówczas klub pod nazwą «Unia», zrzeszający wychowanków szkoły generała Pawła Chrzanowskiego. Zaczęło się konsolidować życie stowarzyszenia. Pierwszym jego prezesem został ówczesny minister zdrowia, jednocześnie doskonały organizator, dr Czesław Wroczyński [...]. Wiosną I930 roku za sprawą Stowarzyszenia odbył się wielki zjazd Chrzanowiaków z udziałem wychowanków Gimnazjum im. Jana Zamoyskiego i profesorów. Wszyscy uczestnicy oraz ówczesna młodzież szkolna otrzymali okolicznościowy znaczek. Po Mszy świętej, celebrowanej w szkolnej kaplicy przez prefekta księdza dr. Marcina Szkopowskiego w asyście księży wychowanków [...] szkoły, odsłonięto obok ołtarza tablicę z nazwiskami kolegów poległych w latach I9I4-I920, z wyrytą łacińską premią: Dulce et decorum est pro patria mori", zob. 100 lat na Smolnej..., dz. cyt., s. 94

28 Zjazd B. Wychowanków Gimnazjum im. Jana Zamoyskiego w Warszawie, "Rzeczpospolita” I930 nr I25, s. IO.

29 Por. T. Kwiek, Historia gimn. Tow. im. Jana Zamoyskiego..., dz. cyt., s. I I. 
dotyczących głównie rożnych wydarzeń związanych z aktualnymi rocznicami historycznymi czy rozważań etycznych, niepozbawionych akcentów moralizatorskich ${ }^{3}$.

Lata szkolne w gimnazjum na Smolnej 30, oprócz zdobywanej wiedzy oraz działalności w Samopomocy, były czasem nawiązania przez gimnazjalistów nowych przyjaźni niezależnych od wyznawanego światopoglądu. Najlepszym szkolnym przyjacielem wspomnianego Mosdorfa, był kolega z klasy maturalnej Antoni Boniecki, późniejszy działacz Komunistycznego Związku Młodzieży Polskiej (KZMP), w latach 30. XX wieku redaktor naczelny „Kultury Mas”, ukrywający się pod pseudonimem Andrzej Wasilewski ${ }^{{ }^{1}}$. Pomimo zasadniczej różnicy w poglądach, jak wspominał relacje uczniów gimnazjum polonista Nowak-Dłużewski, „obaj ci ideologiczni przeciwnicy świecili przykładem kulturalnego współżycia koleżeńskiego, często się ze sobą kłócili, ale stale, jak mi mówiono, ze sobą przestawali”32.

Inny przykład może stanowić gimnazjalna przyjaźń Kwasieborskiego ze znanym pianistą Witoldem Małcużyńskim, „obaj świetni uczniowie, obaj czynni w organizacjach szkolnych. Kwasieborski wyróżniał się już w szkole [...], zapowiadając niepośledni talent dyskusyjny; czytelnik pism Romana Dmowskiego, był wyznawcą ideologii narodowo-demokratycznej [...]. Małcużyński był politycznie na biegunie przeciwległym: sympatiami lgnął do liberalnej inteligencji warszawskiej [...]. Pamiętam jak na jakimś szkolnym organizacyjnym zebraniu mówił mi Kwasieborski, pokazując na Małcużyńskiego: niech pan profesor nie wierzy temu masonowi. A na to Małcużyński: niech pan nie wierzy temu endekowi. A po zebraniu w najlepszej zgodzie szli sobie do domu,

30 Por. M. Korwin-Piotrowski, Co w pyle dawnych akt..., dz. cyt., s. 34; A. Dudek, G. Pytel, Bolestaw Piasecki: próba biografii politycznej, Londyn I990, s. I2.

3 I K. Sierocka, Polonia radziecka, 1917-1939: z działalności kulturalnej i literackiej, Warszawa ı968, s. I Iо.

32 J. Nowak-Dłużewski, Ze wspomnień polonisty..., dz. cyt., s. I05. 
odprowadzając się wzajemnie. Nie było lepszych przyjaciół, bardziej szanujących się wzajemnie, jak ci dwaj obiecujący młodzi ludzie" ${ }^{33}$.

Często starsi uczniowie gimnazjum oddziaływali na młodszych, kształtując ich postawy życiowe i polityczne. Jerzy Tymiński, uczeń gimnazjum w latach I924-I933, wspominał, jak będąc w VI klasie, wraz z kilkoma kolegami postanowił organizować spotkania dyskusyjne, podczas których każdy wygłaszał referat na najważniejszy czy najciekawszy dla siebie temat: „Na jesieni I930 roku miałem lat piętnaście i byłem w klasie VI. Snuły mi się po głowie plany bliżej nieokreślonej pracy społecznej, konieczność działania, organizowania, reformowania. Nie byłem w tym odosobniony. Jakoś się zgadało z kilkoma kolegami i postanowiliśmy spotykać się co tydzień dla dyskutowania spraw, które wydawały nam się ważne" 34 .

Przed jednym z takich spotkań do Tymińskiego miał podejść rozpoznawalny już w gimnazjum ówczesny prezes samopomocy gimnazjalnej, uczeń klasy maturalnej Bolesław Piasecki, prosząc o spotkanie i zapraszając młodszego kolegę do własnego domu. To przeżycie mocno utkwiło w pamięci gimnazjalisty. Po latach wspominał: „Zaproszenie było zaszczytne. Po pierwsze: ja w szóstej, a on w ósmej. Ja skromny członek Samorządu Klasowego, on - prezes całej szkolnej republiki. Poza tym i do szóstaków dochodziły już słuchy, że to jakiś mądry człowiek" 35 .

Tymiński skorzystał z zaproszenia starszego kolegi, które wywarło na nim ogromne wrażenie. Jak relacjonował spotkanie:

[...] przyjął mnie w ciasnym pokoju pełnym książek. Usiedliśmy i zapadło długie milczenie. Chrząknąłem. Raz i drugi! Cisza, wreszcie: - Słyszałem, że organizujesz zebrania? - No, tak, takie sobie dyskusje. Ciekawe, skąd o tym wie? Znowu milczenie. - Więc właśnie... w związku z tym zebraniem. Chciałem $\mathrm{z}$ tobą porozmawiać o ważnych sprawach. - Słucham więc. Długie milczenie. Bolesław długo się zastanawiał, przyglądał, medytował, wreszcie zadał mi pytanie: - Ale najpierw powiedz mi... do czego właściwie dążysz w życiu? Co chcesz w życiu osiągnąć́? Pytanie trochę mnie zatkało, odpowiedziałem dość

33 J. Nowak-Dłużewski, Ze wspomnień polonisty..., dz. cyt., s. I05.

34 J. Tymiński, Szkolne migawki, w: Smolna 30..., dz. cyt., s. I32.

35 J. Tymiński, Szkolne migawki, w: Smolna 30..., dz. cyt., s. I33. 
górnolotnie, ale szczerze. O ideale pełnego człowieka. O ambicji trzymania się w czołówce, o pracy dla społeczeństwa. Znowu o ambicji. Tu Bolesław mi przerwał: - Masz rację, mówiąc o ambicji. Ambicja to ważna rzecz. Ale wtedy jest tylko ważna, jeżeli wciąż, codziennie uzasadniona wynikami pracy nad sobą. To zdanie zapamiętałem, bo ważne, i myślę, że jest nadal ważne, że powinno być ważne dla dzisiejszej i dla każdej młodzieży. Trzeba mieć ambicję i trzeba tę ambicję uzasadniać. Prosta sprawa. Teraz rozmowa potoczyła się szybciej. O sytuacji w Polsce. O tym, że za kilka lat będziemy ludźmi dojrzałymi. O sytuacji w szkole, w której już możemy i powinniśmy sami się przygotowywać do pracy w społeczeństwie dorosłych...

Podsumowując rozmowę, Tymiński dodał, że: „Nie była to jedyna rozmowa z Bolesławem na te i podobne tematy. Muszę przyznać, że ten kontakt wywarł znaczny wpływ na ukształtowanie mojej osobowości" ${ }^{36}$.

\section{CO DAJE NAM SZKOŁA DLA ŻYCIA?}

Szkoła stanowi jedną z najważniejszych organizacji społecznych w życiu każdego człowieka, w której oprócz zdobywania wiedzy rodzą się przyjaźnie na całe życie oraz kształtują postawy społeczne i polityczne. W Księdze Pamiątkowej maturzystów z I93I roku7 Piasecki w tekście Co dała nam szkoła dla życia, wspominając lata spędzone w gimnazjum na Smolnej 30 w Warszawie, pisał m.in. „Pamiętacie tę chwilę: byliśmy jeszcze zupełnie mali i dziecinnie rozpieszczeni. Przychodziliśmy do szkoły z mnóstwem niekojących pytań. Po co w ogóle trzeba się uczyć, jak się ustosunkować do profesorów i ich długich wykładów, etc., etc.?" ${ }^{8}$.

36 J. Tymiński, Szkolne migawki, w: Smolna 30..., dz. cyt., s. I34.

37 Księga ukazała się w liczbie sześćdziesięciu egzemplarzy, jej wydawcą i redaktorem był Piasecki, a fundusze na pokrycie kosztów druku pochodziły z kasy Samopomocy Koleżeńskiej. Księga składa się z rożnej objętości artykułów autorstwa kolegów klasowych Piaseckiego, otwierał ją wstęp samego redaktora. Zob. A. Dudek, G. Pytel, Bolestaw Piasecki..., dz. cyt., s. I8.

38 B. Piasecki, Co dała nam szkoła, w: Księga pamiątkowa maturzystów, Warszawa I93 I, cyt. za: B. Piasecki, Co dała nam szkoła, w: Smolna 30..., dz. cyt., s. 2I6-2I7. 
Według Piaseckiego szkoła dała uczniom trzy główne dobrodziejstwa: po pierwsze - wiedzę, po drugie - naukę życia społecznego, czyli umiejętność obcowania z ludźmi, po trzecie - doświadczenie życiowe. Jak wielkie znaczenie nauka w szkole może wywierać na postawę życiową młodego maturzysty, niech zaświadczą słowa późniejszego działacza „Falangi”: „Zaopatrzeni przez szkołę w te trzy przymioty, [...] stajemy do walki o przyszłość naszą. Stajemy także z myślą, że osiągnąwszy ją w sposób szlachetny, spłacimy dług wdzięczności zaciągnięty wobec szkoły. Stajemy silni, zdecydowani, wytrwali i pewni zwycięstwa. A zatem: «Niech żyje walka o zamierzone przez nas cele!»”39.

\section{ZAKOŃCZENIE}

Na początku lat 30. XX wieku, w czasie przeprowadzanej przez „sanację" reformy szkolnictwa oraz tworzenia nowej ideologii wychowawczej - wychowania państwowego, gdzie państwo miało być głównym organizatorem życia zbiorowego ${ }^{40}$, zarzucano dyrektorowi Henrykowi Lipskiemu szerzenie antysanacyjnej atmosfery. W konsekwencji w roku szkolnym I932/33 gimnazjum straciło najwyższą kategorię A, co oznaczało rozszerzenie egzaminu maturalnego o kilka przedmiotów i nadzór nad przebiegiem egzaminu delegata kuratorium. Szkoła straciła także kilku zasłużonych, oddanych nauczycieli. Dyrektor Lipski złożył dymisję, a I września I933 roku nowym dyrektorem został dr Jan Dąbrowski, dotychczasowy wizytator Kuratorium Warszawskiego4i.

Współcześnie na Smolnej 30 w Warszawie znajduje się XVIII Liceum Ogólnokształcące im. Jana Zamoyskiego, na stronie interneto-

39 B. Piasecki, Co dała nam szkoła, w: Księga pamiątkowa maturzystów, dz. cyt., cyt. za: B. Piasecki, Co dała nam szkoła, w: Smolna 30..., dz. cyt., s. 216-2I7.

40 Por. M. A. Jakubiak, Ideologia wychowania sanacji, ,Saeculum Christianum” I (2003), s. 255 .

4I Zob. Historia Szkoły. Sto lat na Smolnej. W odrodzonej Rzeczypospolitej (19181939), http://zamoyski.edu.pl/backup/index.php?strona=dane_o_szkole\&podstrona=historia_szkoly_p2 (I5.08.20I8); T. Kwiek, Historia gimn. Tow. im. Jana Zamoyskiego..., dz. cyt., s. I I. 
wej liceum oraz w pracy 100 lat na Smolnej, czpli dzieje Gimnazjum $i$ Liceum Jana Zamoyskiego $w$ Warszawie ${ }^{42}$ wśród wymienionych wybitnych absolwentów (m.in. Jerzego Giedroycia) o przedwojennych wszechpolakach i oenerowcach jak Jan Mosdorf czy Bolesław Piasecki się nie wspomina ${ }^{43}$.

\section{BIBLIOGRAFIA}

I. ŹRÓDモA

Echa walnego zebrania, „Kuźnica: Dwutygodnik Młodzieży Demokratycznej” 4 (I928), s. 2.

Gimnazjum Towarzystwa Szkoły Maurycego Hr. Zamoyskiego. Sprawozdanie z Działalności Towarzystwa Szkoły Maurycego Hr. Zamoyskiego w Roku Szkolnүm 1915/16, Warszawa 1916.

Korwin-Piotrowski, M., Co w pyle dawnych akt o samorządzie znaleźć można, „Życie Szkoły: Organ Samorządu Szkolnego Uczniów Gimnazjum im. Jana Zamoyskiego" 65 (I938), s. 3I-37.

Kwiek, T., Historia gimn. Tow. im. Jana Zamoyskiego. Lista nauczycieli gimnazjum i szkoły powszechnej Tow., „Życie Szkoły: Organ Samorządu Szkolnego Uczniów Gimnazjum im. Jana Zamoyskiego" 65 (1938), s. 3-20.

Kwiek, T., Nasza Szkoła 1905-1939, w: Smolna 30: Gimnazjum im. Jana Zamoyskiego, red. J. Durko, T. Kwiek, Warszawa I989, s. 13-40.

Nowak-Dłużewski J., Ze wspomnień polonisty Gimnazjum im. Jana Zamoyskiego (1920-1939). (Na pótwieczny jubileusz szkoły), „Życie i Myśl” 9 (I965), s. 99-107.

Pejsate wojowniki, zawodowi pacyfiści, dezerterzy i tchórze w roli nauczycieli... męstwa, „Falanga. Pismo Narodowo-Radykalne” 6 (I937), s. 4.

42100 lat na Smolnej..., dz. cyt., s. 49.

43 Absolwenci, http://zamoyski.edu.pl/szkola/historia-i-tradycja/absolwenci/ (I5.08.20I8). 
Piasecki B., Co dała nam szkoła, w: Smolna 30: Gimnazjum im. Jana Zamoyskiego, red. J. Durko, T. Kwiek, Warszawa ig89, s. 215-2I7.

Tymiński, J., Szkolne migawki, w: Smolna 30: Gimnazjum im. Jana Zamoyskiego, red. J. Durko, T. Kwiek, Warszawa ı989, s. І32-136.

Wańkowicz, M., Przez trzy epoki, w: Smolna 30: Gimnazjum im. Jana Zamoyskiego, red. J. Durko, T. Kwiek, Warszawa I989, s. II3-II9.

Zagórski J., Wywołani do tablicy, w: Smolna 30: Gimnazjum im. Jana Zamoyskiego, red. J. Durko, T. Kwiek, Warszawa ı989, s. ı62-166.

Zjazd B. Wychowanków Gimnazjum im. Jana Zamoyskiego w Warszawie, „Rzeczpospolita” I930 nr I25, s. Io.

\section{OPRACOWANIA I ARTYKUEY NAUKOWE}

Dudek, A., Pytel, G., Bolesław Piasecki: próba biografii politycznej, Londyn I990.

Garliński, J., Oświęcim walczący, Londyn I974.

Gawron, W., Ochotnik do Oświęcimia, Oświęcim I992.

Jakubiak, M. A., Ideologia wychowania sanacji, ,,Saeculum Christianum” I (2003), s. 253-266.

Kamiński, S., Miałem piętnaście lat. Pawiak był etapem. Wspomnienia lat 19391944, Warszawa I987.

Kotas, M., Jan Mosdorf. Filozof, ideolog, polityk, Krzeszowice 2007.

Miąso, J., Walka o narodowa szkołę w Królestwie Polskim w latach 1905-1907 (w stulecie strajku szkolnego), „Rozprawa z Dziejów Oświaty” 44 (2005), S. 75-103.

Sierocka, K., Polonia radziecka, 1917-1939: z działalności kulturalnej i literackiej, Warszawa I968.

Tyszka, K. A., Związki młodziė̇y narodowej. Rys historyczny procesu powstawania Młodzieży Wszechpolskiej w Warszawie 1915-1922, „Glaukopis” 4 (2006), s. 9-68. 
100 lat na Smolnej, czpli dzieje Gimnazjum i Liceum Jana Zamoyskiego w Warszawie, oprac. aut. U. Golnik-Szczególska, M. Szczygielska, B. Kozyra; współpr. A. Grocholska, E. Kędziorek, Warszawa 2005.

Absolwenci, http://zamoyski.edu.pl/szkola/historia-i-tradycja/absolwenci/ (15.08.2018).

Historia Szkoły. Sto lat na Smolnej. W odrodzonej Rzeczypospolitej (1918-1939), http://zamoyski.edu.pl/backup/index.php?strona=dane_o_szkole\&podstrona=historia_szkoly_p2 (I5.08.2018). 


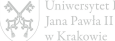

